\title{
Comparison between gamma irradiation and plasma technology to improve the safety of cold sliced chicken
}

\author{
Ahmed A. Aly ${ }^{1}$ and G.M.El-Aragi ${ }^{2}$ \\ ${ }^{1}$ Home Economic Department, Faculty of Specific Education, Benha University, Egypt. \\ ${ }^{2}$ Plasma Physics and Nuclear Fusion Department, Nuclear Research Center, AEA, PO 13759 Cairo, Egypt.
}

Accepted 31 October, 2013

\begin{abstract}
The aim of this study was to determine the impact of gamma irradiation and plasma treatment on quality (appearance, odor and texture) and safety (total bacteria count, psychrophilic bacteria, spore forming bacteria, total molds and yeasts) of cold sliced chicken. Pulsed atmospheric-pressure plasma jet (PAPPJ) device is used for the treatment of fresh sliced chicken with different exposure time. Also, another sliced chicken samples were subjected to different gamma irradiation doses. The results illustrate that gamma irradiation and plasma treatment had no real effect on the chemical composition of sliced chicken and the effects of these treatments on the microbial load are reduced the counts of total bacteria, psychrophilic bacteria, total molds and yeasts count. Gamma irradiation and plasma treatment had no effects on the sensory characteristics for appearance, odor and texture of all sliced chicken samples. Finally, gamma irradiation and plasma treatment had no adverse effects on the sensory properties of sliced chicken samples, therefore, their use as safety technological treatments in food preservation and extending shelf-life.
\end{abstract}

Key words: Gamma irradiation, plasma, chicken, microbial load.

\section{INTRODUCTION}

Poultry carcasses are commonly contaminated with enteric pathogens such as Salmonella, Campylobacter and Listeria monocytogenes (Jacobsreitsma et al., 1994; Murphy et al., 2004); the possibility of cross-contamination of poultry carcasses post slaughter is high. Decontamination of poultry carcasses is therefore desirable. Various decontamination technologies have been proposed including the use of various chemical agents such as alkali (Rodriguez et al., 1996), physical methods such as steam treatment (James et al., 2007) and biological control with bacteriophages (Carvalho et al., 2010), but only treatment with water supplemented with chlorine or a chlorineting agent is used commercially. The effects of such decontaminating treatments are limited (Oyarzabal, 2005; Russell and Axtell, 2005).
Plasma is matter that contains partially or wholly ionized gas with a net neutral charge and is often referred to as the fourth state of matter as it shares properties similar to both those of gases and liquids. Plasma is created under energy deposition into gaseous mixture. Gas turns into plasma due to ionization, dissociation and excitation of the bound states of atoms and molecules of the background gas. Therefore, plasma consists of gaseous mixture of charged particles (free electrons and ions) and neutral activated species including gas molecules, free radicals, metastables and ultraviolet photons. Energetic electrons generate intensively numerous chemical active species due to collisions with atoms and molecules. In the gas mixture containing oxygen and water vapor, most of the primary radicals are $\mathrm{O}$ and $\mathrm{OH}$. 
Numerous components of plasma such as for example reactive oxygen or nitrogen species, charged particles, electric fields and even UV light are involved in these effects. Hence, they are widely used in a broad spectrum of applications ranging from low temperature plasma chemistry, decomposition of gaseous pollutants, light sources, surface modification to medical sterilization and microbial decontamination (Kogelschatz, 2004; Becker et al., 2005; Foest et al., 2005; Ehlbeck et al., 2008; Massines et al., 2012; Ehlbeck et al., 2011).Cold plasma produces (gaseous) activated ions, pho-tons, electrons and free radicals, collectively termed 'plas-ma', that exert their effects at 30 to $60^{\circ} \mathrm{C}$; hence the term 'cold' or nonthermal.

Plasma may inactivate both vegetative cells and bacterial endospores. Synergistic effects between these possible mechanisms of inactivation can be expected, depending on the operational conditions and the design of the plasma generator.

Recent investigations which include the evaluation of the inactivation of food-borne pathogens seeded on to thin films of agar, treated with a glow discharge plasma (Kayes et al., 2007) and also sprayed onto the surface of heat sensitive polyethylene terephthalate (PET) foils, exposed to a dielectric barrier discharge (Muranyi et al., 2007; Yu et al., 2006), reported that high loadings of Escherichia coli on polycarbonate membranes adversely affected the penetration of plasma species and the effectiveness of microbial inactivation. Cold atmospheric plasmas (CAP) or non-thermal plasmas have been reported to be very effective against a wide range of microorganisms, including biofilm-formers and bacterial spores (Montie et al., 2000; Deng et al., 2005; Vleugels et al., 2005).

Implementation of an emerging technology such as CAP, in food preservation, depends on reliable estimations of its efficacy against pathogenic and food spoilage microorganism and to reach this objective it is necessary to understand the factors which affect microbial resistance (Fernández et al., 2012). Among these factors, the effect of initial cell concentration is known to be one of the most relevant in food surface treatment strategies (Deng et al., 2005; Moreau, 2000).

In general, during inactivation of microorganisms on surfaces, the rate of inactivation is inversely proportional to the initial cell concentration (Shintani, 2000). Food irradiation is being considered an important tool, in ensuring safety and extending shelf-life of fresh meat and poultry (Yoon, 2003). Thus irradiation can eliminate food-borne pathogenic microorganisms in meat. Furthermore, the use of gamma irradiation as a safety techno-logical treatment in food preservation has now become legally accepted in many countries of the world (Abdel-Daium, 2007).

Therefore, in this work, we examined the efficacy of cold atmospheric plasma to inactivation of microbial load in sliced chicken compared to gamma radiation.

\section{MATERIALS AND METHODS}

Sliced chicken were purchased from local market (Benha, Qaliobia governorate, Egypt). All samples were transported to our laboratory food irradiation unit, Nuclear Research Center in ice-box $\left(0^{\circ} \mathrm{C}\right)$ and surveyed for microbiological counts for counts of total bacteria, psychrophilic bacteria, spore forming bacteria, total molds and yeasts. Then, sliced chicken samples were packed in tightly sealed polyethylene pouches and divided into seven groups and stored in freezing till irradiation treatments.

\section{Gamma irradiation treatments}

Four bags from each of sliced chicken were gamma irradiated at 0 , 2,4 , and $6 \mathrm{kGy}$ doses using cobalt-60 gamma chamber (1.367 $\mathrm{kGy} / \mathrm{h}$ ) in Cyclotron Project, Nuclear Research Center Atomic Energy Authority, Inshas, Cairo, Egypt. After irradiation, all samples were stored at $4 \pm 1^{\circ} \mathrm{C}$.

\section{Plasma treatments}

\section{Character of exposure machine}

The plasma generator consisted of a negative dc source, a Blumlein-type pulse-forming network (E-PFN), and a dynamic spark gap switch. A triggered spark gap switch was used as a closing switch of E-PFN. E-PFN had four stages of LC ladder, which were composed of $5 \mathrm{nF}$ of capacitor and $3 \mu \mathrm{H}$ of inductor. The characteristic impedance $(2 \sqrt{L} / C)$ and the pulse width $(2 \mathrm{~N} \sqrt{ } \mathrm{LC})$ of $\mathrm{E}$ PFN, calculated from capacitance $(C)$ and inductance $(L)$ of the LC ladder, and number $(\mathrm{N})$ of LC ladder stages were approximately 49 $\Omega$ and $1.0 \mu \mathrm{s}$, respectively.

A charging resistance value of $50 \mathrm{k} \Omega$ was chosen in the present case which corresponds to a charging RC time constant of $1 \mathrm{~ms}$, which is 40 times faster compared to the repetition rate of the pulse.

A schematic of the pulsed atmospheric-pressure plasma jet (PAPPJ) device for generating high voltage pulsed, cold atmospheric plasma jets is shown in Figure 1. The high voltage $(\mathrm{HV})$ wire electrode, which is made of a copper wire, is inserted into a hollow barrel of a syringe. The distance between the tip of the HV electrode and the nozzle is $0.5 \mathrm{~cm}$.

When HV pulsed, DC voltage (amplitudes up to $25 \mathrm{kV}$, repetition rate up to $25 \mathrm{~Hz}$ ), was applied to the HV electrode and helium gas was injected into the hollow barrel. This device was made using medical syringe (made out of an insulating material cylinder). The gas was fed into the system via flow meter.

The applied voltage to and the discharge current through the discharge chamber were measured using a voltage divider (Homemade), which was connected between the two electrodes, and a current monitor, which can be located upon returning to the ground. The signals from the voltage divider and the current monitor were recorded in a digitizing oscilloscope (Lecroy, USA) with a $200-\mathrm{MHz}$ bandwidth.

The high voltage pulses are applied between the needle electrode positioned inside a dielectric cylinder (a simple medical syringe) and a metal ring placed on the exterior of this cylinder. In order to obtain electric discharges at atmospheric pressure, a high voltage pulses (tens of $\mathrm{kV}$ ) which have limited duration (hundreds of nanoseconds) and are repeated (tens of pulses per second), in addition to an inert gas (argon) is introduced in the cylinder.

The gas flows were in the range $0.5-10 \mathrm{l} / \mathrm{min}$. The discharge takes place between the metallic needle top and a metallic ring fit on the outer surface of the syringe. Under optimal conditions, plasma is emitted as centimeter-long jets, just millimeters in 


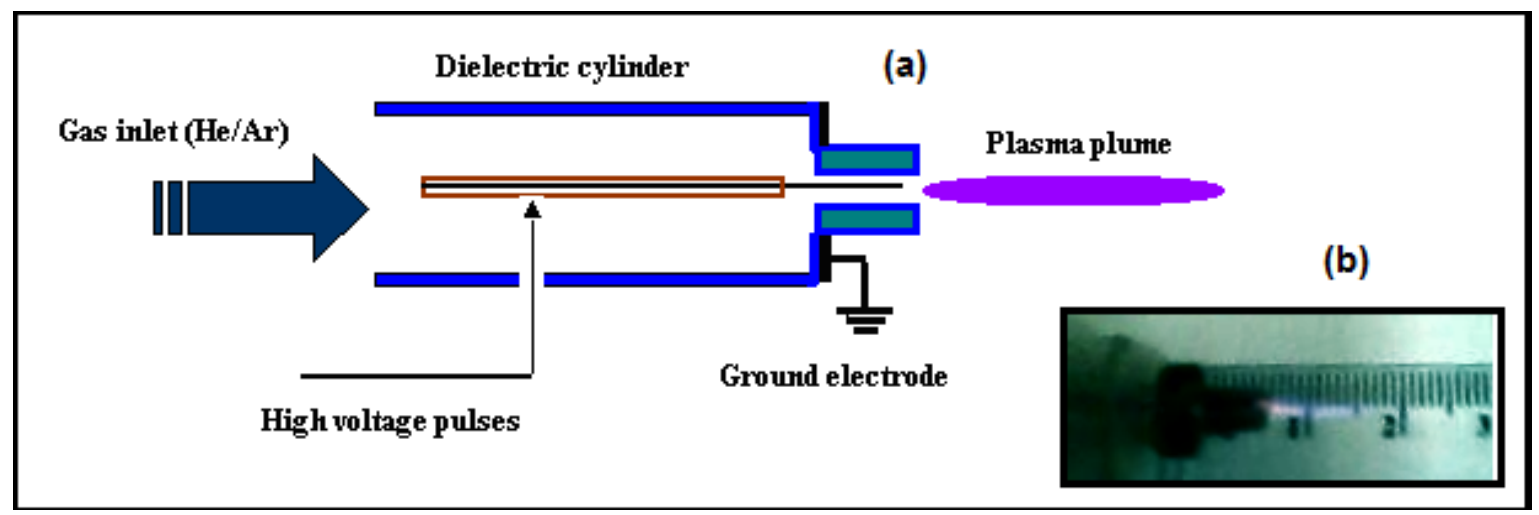

Figure 1. Schematic diagram of the plasma jet generator. (b) Image of the plasma jet with argon gas.

Table 1. Effect of gamma irradiation and plasma treatment on chemical composition of sliced chicken.

\begin{tabular}{|c|c|c|c|c|c|c|c|}
\hline \multirow{3}{*}{ Chemical composition \% } & \multicolumn{7}{|c|}{ Treatments } \\
\hline & \multicolumn{4}{|c|}{ Gamma irradiation doses } & \multicolumn{3}{|c|}{ Exposure time of plasma (min) } \\
\hline & 0 kGy & $2 \mathrm{kGy}$ & 4 kGy & $6 \mathrm{kGy}$ & 0.5 & 1.0 & 1.5 \\
\hline Moisture & 76.133 & 76.133 & 76.367 & 76.200 & 75.833 & 75.567 & 76.267 \\
\hline Total Protein & 87.633 & 86.273 & 86.530 & 86.387 & 86.723 & 87.006 & 86.340 \\
\hline lipid & 5.190 & 5.6133 & 5.353 & 5.550 & 5.410 & 5.453 & 5.320 \\
\hline Ash & 5.5167 & 5.800 & 5.800 & 5.317 & 5.967 & 5.627 & 5.390 \\
\hline
\end{tabular}

diameter or even smaller.

The working gases are supplied by high-pressure cylinders. Gas pressure regulators are used to reduce the pressure of gases to a workable level. Then, gas flow controllers deliver the gases with the desired flow. For voltage amplitudes of $15-18 \mathrm{kV}$, the plasma jet is very weak. The plasma jet disappears for voltage amplitudes lower than $15 \mathrm{kV}$.

When argon is injected from the gas inlet and high voltage pulses, $26 \mathrm{kV}$ voltages is applied to the electrode, the plasma jet is generated and a plasma plume reaching length of $21 \mathrm{~mm}$ is launched through the end of the tube and in the surrounding air. The length of the plasma plume can be adjusted by the gas flow rate and the applied voltage.

Three bags from each of sliced chicken were exposured to plasma at $0.5,1.0$ and $1.5 \mathrm{~min}$ in Plasma Physics and Nuclear Fusion Department, Nuclear Research Center, Atomic Energy Authority, Inshas, Cairo, Egypt. After the exposure time of plasma, all samples were stored at $4 \pm 1^{\circ} \mathrm{C}$.

\section{Microbial analysis}

Colony forming units for total bacterial count were counted by plating on plate count agar medium and incubated at $30^{\circ} \mathrm{C}$ for three to five days (APHA, 1992). Total molds and yeasts were counted on oxytetracycline glucose yeast extract agar medium according to Oxoid, (1998). psychrophilic and spore forming bacteria count according to (FDA, 2002).

\section{Statistical analysis}

The statistical evaluation of the mean data was compared using one-way analysis of variance (ANOVA) according to Zar (1984). The chosen level of significance was $P \leq 0.05$.

\section{RESULTS AND DISCUSSION}

\section{Chemical composition}

The effect of various gamma irradiation doses on the chemical composition of sliced chicken was studied and the data and its analysis of variance are illustrated in Tables 1 and 2. From Table 1, it could be noticed that the moisture total protein, lipid and ash contents were 76.133, 87.633, 5.190 and $5.5167 \%$ for control (0 kGy) sliced chicken respectively.

From data in Tables 1 and 2, it could be noticed that there was no significant changes $(P \leq 0.05)$ in the chemical analysis of sliced chicken irradiated with gamma doses (2, 4, and $6 \mathrm{kGy}$ ) and exposed to plasma at 0.5 , 1.0 and $1.5 \mathrm{~min}$ compared to non irradiated sample.

\section{Microbial evaluation}

Bacterial aspects of untreated and treated sliced chicken samples with gamma irradiation and plasma during cold storage at $\left(4 \pm 1^{\circ} \mathrm{C}\right)$ were enumerated and the data are recorded in Table 3 . The initial total bacteria count, psychrophilic bacteria, spore forming bacteria, total molds 
Table 2. Analysis of variance for the effect of gamma irradiation and plasma treatment on chemical composition of sliced chicken.

\begin{tabular}{|c|c|c|c|c|c|c|c|}
\hline $\begin{array}{l}\text { Chemical } \\
\text { composition }\end{array}$ & Source of variation & SS & $\begin{array}{l}\text { Degree of } \\
\text { freedom }\end{array}$ & $\begin{array}{l}\text { Main square } \\
\text { values }\end{array}$ & $\mathbf{F}$ & P-value & F crit \\
\hline & Between groups & 1.382 & 6 & $0.231^{\mathrm{NS}}$ & 0.039 & 1 & 2.848 \\
\hline \multirow[t]{3}{*}{ Moisture } & Within groups & 82.26 & 14 & 5.876 & & & \\
\hline & Total & 83.642 & 20 & & & & \\
\hline & Between groups & 4.212 & 6 & $0.702^{N S}$ & 0.399 & 0.867 & 2.848 \\
\hline \multirow[t]{3}{*}{ Total protein } & Within groups & 24.611 & 14 & 1.758 & & & \\
\hline & Total & 28.823 & 20 & & & & \\
\hline & Between groups & 0.3674 & 6 & $0.061^{N S}$ & 0.242 & 0.955 & 2.848 \\
\hline \multirow[t]{3}{*}{ Lipid } & Within groups & 3.542 & 14 & 0.253 & & & \\
\hline & Total & 3.9092 & 20 & & & & \\
\hline & Between groups & 1.0193 & 6 & $0.170^{N S}$ & 0.694 & 0.659 & 2.848 \\
\hline \multirow[t]{2}{*}{ Ash } & Within groups & 3.4271 & 14 & 0.245 & & & \\
\hline & Total & 4.446 & 20 & & & & \\
\hline
\end{tabular}

NS, Non significant.

and yeasts of non-treated sliced chicken were high counts $\left(5.6 \times 10^{2}, 9.0 \times 10^{2}, 71 \times 10^{1}\right.$ and $6.3 \times 10^{2} \mathrm{cfu} / \mathrm{g}$, respectively) while treatment sliced chicken by gamma irradiation at doses (2, 4 and $6 \mathrm{kGy})$ and plasma treatment $(0.5,1,1.5 \mathrm{~min})$ reduced the counts of microbial loads.

The best antimicrobial treatments which com-pletely eliminated psychrophilic bacteria were noticed in sliced chicken samples treated by gamma irradiation at dose 4 $\mathrm{kGy}$ followed by plasma at $1.5 \mathrm{~min}$. Furthermore, the use of these doses extended the shelf-life of sliced chicken to 27 and 23 days, respectively compared to seven days for untreated samples under cold storage $\left(4 \pm 1^{\circ} \mathrm{C}\right)$.

\section{Sensory evaluation}

Sensory evaluation is a common and very useful tool in quality assessment of processed meat products. It makes use of the senses to evaluate the general acceptability and quality attributes of the products.

Tables 4 and 5 show the changes in sensory evaluation of sliced chicken as affected by gamma irradiation and plasma treatment during storage period at $4 \pm 1^{\circ} \mathrm{C}$ temperature. From these results, it is noticed that gamma irradiation and plasma treatment had no remarkable effect on sensory properties (appearance, odor and texture) of sliced chicken under investigation at zero time of storage period.

Tables 4 and 5 also show the appearance, odor and texture during storage temperature $\left(4 \pm 1^{\circ} \mathrm{C}\right)$. At the beginning of cold storage $\left(4 \pm 1^{\circ} \mathrm{C}\right.$ ) (zero time), no significant difference $(P \leq 0.05)$ was found between the samples which were irradiated with gamma rays at 0,2 , 4, $6 \mathrm{kGy}$ and exposed to plasma treatment at $0.5,1.0,1.5$ min. A significant difference $(P \leq 0.05)$ was shown in all treated samples after four days.

It was observed that the reference sample were rejected being samples that had been contaminated on day 8 of storage while irradiated with gamma rays (2 $\mathrm{kGy}$ ) and exposure to plasma treatment $(0.5 \mathrm{~min}$.) were scored as poor and rejected on day 12. It has been found that irradiated samples at $6 \mathrm{kGy}$ and those exposed to plasma treatment at $1.5 \mathrm{~min}$ were better than other samples.

This may be due to the effect of gamma irradiation dose (6 kGy) and exposure to plasma treatment (1.5 min) improves the appearance, odor and texture by inhibition of the microbial load and discoloration of the surface. It was noticed that a small spots of mold growth appeared on the surface of irradiated samples at doses of 4 and 6 kGy and were rejected on day 16 and 28 of storage respectively.

On the other hand, sliced chicken samples were exposed to plasma treatment at 0.5 and $1 \mathrm{~min}$ and were rejected being samples that had been contaminated on day 16 and 24 of storage respectively.

Gamma irradiation and plasma treatments of sliced chicken samples have the same extended shelf-life up to 27 and 23 day respectively compared to non- treated samples during cold storage $\left(4 \pm 1^{\circ} \mathrm{C}\right)$.

\section{Conclusion}

Cold or non-thermal plasma has several advantages over 
Table 3. Effects of gamma irradiation and plasma treatment on microbial load in sliced chicken during cold storage $\left(4 \pm 1^{\circ} \mathrm{C}\right)$.

\begin{tabular}{|c|c|c|c|c|c|c|c|c|}
\hline \multirow{3}{*}{$\begin{array}{l}\text { Microbial } \\
\text { decontamination } \\
\text { (cfu/g) }\end{array}$} & \multirow{3}{*}{$\begin{array}{l}\text { Storage } \\
\text { period } \\
\text { (days) }\end{array}$} & \multicolumn{7}{|c|}{ Treatment } \\
\hline & & \multicolumn{4}{|c|}{ Gamma irradiation dose } & \multicolumn{3}{|c|}{$\begin{array}{c}\text { Time of cold atmospheric plasma } \\
\text { (min) }\end{array}$} \\
\hline & & 0 kGy & 2 kGy & 4 kGy & $6 \mathrm{kGy}$ & 0.5 & 1 & 1.5 \\
\hline \multirow{8}{*}{ Total bacteria counts } & 0 & $5.6 \times 10^{2}$ & $2.5 \times 10^{2}$ & $6.2 \times 10^{1}$ & $5.1 \times 10^{1}$ & $2.9 \times 10^{2}$ & $2.8 \times 10^{2}$ & $1.9 \times 10^{2}$ \\
\hline & 4 & $1.1 \times 10^{3}$ & $4.2 \times 10^{2}$ & $7.1 \times 10^{1}$ & $6.8 \times 10^{1}$ & $8.5 \times 10^{2}$ & $4.8 \times 10^{2}$ & $4.0 \times 10^{2}$ \\
\hline & 8 & $8.0 \times 10^{3} \AA$ & $5.0 \times 10^{2}$ & $7.9 \times 10^{1}$ & $7.5 \times 10^{1}$ & $6.8 \times 10^{3}$ & $5.9 \times 10^{3}$ & $5.2 \times 10^{2}$ \\
\hline & 12 & & $1.7 \times 10^{3} \AA$ & $1.9 \times 10^{2}$ & $1.3 \times 10^{2}$ & $8.8 \times 10^{3} \AA$ & $6.2 \times 10^{3}$ & $5.9 \times 10^{3}$ \\
\hline & 16 & & & $6.9 \times 10^{3} \AA$ & $4.0 \times 10^{3}$ & & $8.9 \times 10^{3} \AA$ & $8.0 \times 10^{3}$ \\
\hline & 20 & & & & $8.5 \times 10^{3}$ & & & $9.3 \times 10^{3}$ \\
\hline & 24 & & & & $9.5 \times 10^{3}$ & & & $9.0 \times 10^{4} \AA$ \\
\hline & 28 & & & & $9.8 \times 10^{4} \AA$ & & & \\
\hline \multirow{8}{*}{ Psyhcrophilic bacteria } & 0 & $9.0 \times 10^{2}$ & $7.4 \times 10^{2}$ & $4.3 \times 10^{2}$ & Nil & $8.0 \times 10^{2}$ & $3.9 \times 10^{2}$ & Nil \\
\hline & 4 & $7.1 \times 10^{3}$ & $5.9 \times 10^{3}$ & $8.1 \times 10^{2}$ & Nil & $6.1 \times 10^{3}$ & $4.5 \times 10^{3}$ & Nil \\
\hline & 8 & $5.7 \times 10^{4} \AA$ & $8.7 \times 10^{3}$ & $2.1 \times 10^{3}$ & Nil & $9.8 \times 10^{3}$ & $6.3 \times 10^{3}$ & Nil \\
\hline & 12 & & $2.0 \times 10^{4} \AA$ & $4.2 \times 10^{3}$ & Nil & $3.0 \times 10^{4} \circledast$ & $9.2 \times 10^{3}$ & Nil \\
\hline & 16 & & & $2.2 \times 10^{4} \AA$ & Nil & & $1.0 \times 10^{4} \AA$ & Nil \\
\hline & 20 & & & & Nil & & & Nil \\
\hline & 24 & & & & Nil & & & $\mathrm{Nil} \circledast$ \\
\hline & 28 & & & & $\mathrm{Nil} \circledast$ & & & \\
\hline \multirow{8}{*}{ Spore forming bacteria } & 0 & $71 \times 10^{1}$ & $21 \times 10^{1}$ & $12 \times 10^{1}$ & $0.9 \times 10^{1}$ & $32 \times 10^{1}$ & $19 \times 10^{1}$ & $1.3 \times 10^{1}$ \\
\hline & 4 & $98 \times 10^{1}$ & $33 \times 10^{1}$ & $20 \times 10^{1}$ & $1.0 \times 10^{1}$ & $46 \times 10^{1}$ & $31 \times 10^{1}$ & $3.5 \times 10^{1}$ \\
\hline & 8 & $99 \times 10^{1} \circledast$ & $50 \times 10^{1}$ & $32 \times 10^{1}$ & $2.0 \times 10^{1}$ & $70 \times 10^{1}$ & $45 \times 10^{1}$ & $7.0 \times 10^{1}$ \\
\hline & 12 & & $95 \times 10^{1} \AA$ & $64 \times 10^{1}$ & $4.5 \times 10^{1}$ & $98 \times 10^{1} \AA$ & $59 \times 10^{1}$ & $18 \times 10^{1}$ \\
\hline & 16 & & & $97 \times 10^{1} \circledast$ & $21 \times 10^{1}$ & & $100 \times 10^{1} \circledast$ & $30 \times 10^{1}$ \\
\hline & 20 & & & & $50 \times 10^{1}$ & & & $79 \times 10^{1}$ \\
\hline & 24 & & & & $89 \times 10^{1}$ & & & $89 \times 10^{2} \circledast$ \\
\hline & 28 & & & & $99 \times 10^{2} \AA$ & & & \\
\hline \multirow{8}{*}{ Total molds and yeasts } & 0 & $6.3 \times 10^{2}$ & $4.1 \times 10^{2}$ & $3.2 \times 10^{2}$ & $1.3 \times 10^{2}$ & $5.3 \times 10^{2}$ & $4.8 \times 10^{2}$ & $1.5 \times 10^{2}$ \\
\hline & 4 & $8.9 \times 10^{2}$ & $6.9 \times 10^{2}$ & $5.4 \times 10^{2}$ & $3.6 \times 10^{2}$ & $6.8 \times 10^{2}$ & $5.1 \times 10^{2}$ & $3.2 \times 10^{2}$ \\
\hline & 8 & $5.9 \times 10^{3} \AA$ & $9.3 \times 10^{2}$ & $7.8 \times 10^{2}$ & $5.6 \times 10^{2}$ & $9.3 \times 10^{2}$ & $5.4 \times 10^{2}$ & $4.3 \times 10^{2}$ \\
\hline & 12 & & $8.1 \times 10^{3} \circledast$ & $9.9 \times 10^{2}$ & $8.3 \times 10^{2}$ & $3.2 \times 10^{3} \AA$ & $6.3 \times 10^{2}$ & $7.1 \times 10^{2}$ \\
\hline & 16 & & & $2.1 \times 10^{3} \mathbb{B}$ & $23 \times 10^{2}$ & & $5.1 \times 10^{3} \AA$ & $8.0 \times 10^{2}$ \\
\hline & 20 & & & & $9.0 \times 10^{2}$ & & & $9.3 \times 10^{3}$ \\
\hline & 24 & & & & $7.1 \times 10^{3}$ & & & $8.4 \times 10^{4} \circledast$ \\
\hline & 28 & & & & $7.1 \times 10^{4} \AA$ & & & \\
\hline
\end{tabular}

(B): At this point, samples were rejected.

competing preservation technologies such as irradiation (gamma rays), chemical sterilization (ethylene oxide) or disinfection treatments (chlorine). These can have detrimental sensory effects on treated food products or they are being phased out because of safety concerns.
Although cold plasma technology is not yet used commercially on a large scale in the food industry, it has been successfully used for decades in many other industries. Cold plasma systems for treating foods at atmospheric pressure are currently being developed and tested. 
Table 4. Changes in the sensory attributes of sliced chicken as affected by gamma irradiation and plasma treatment during cold storage temperature $\left(4 \pm 1^{\circ} \mathrm{C}\right)$.

\begin{tabular}{|c|c|c|c|c|c|c|c|c|}
\hline \multirow{3}{*}{ Sensory attribute } & \multirow{3}{*}{$\begin{array}{c}\text { Storage } \\
\text { period (days) }\end{array}$} & \multicolumn{7}{|c|}{ Treatments } \\
\hline & & \multicolumn{4}{|c|}{ Gamma irradiation dose } & \multicolumn{3}{|c|}{$\begin{array}{l}\text { Exposure time of } \\
\text { plasma(minute) }\end{array}$} \\
\hline & & 0 kGy & 2 kGy & 4 kGy & $6 \mathrm{kGy}$ & 0.5 & 1 & 1.5 \\
\hline & 0 & 9.73 & 9.70 & 9.69 & 9.72 & 9.74 & 9.63 & 9.72 \\
\hline & 4 & 8.63 & 7.60 & 8.82 & 9.17 & 7.60 & 8.53 & 8.94 \\
\hline \multirow[t]{6}{*}{ Appearance } & 8 & $4.37 \AA$ & 6.67 & 7.10 & 8.37 & 6.63 & 7.63 & 8.45 \\
\hline & 12 & & $4.27 \AA$ & 6.35 & 7.72 & $4.23 \AA$ & 6.37 & 7.72 \\
\hline & 16 & & & $4.22 \circledast$ & 7.02 & & $3.50 \circledast$ & 7.57 \\
\hline & 20 & & & & 6.15 & & & 5.75 \\
\hline & 24 & & & & 5.84 & & & $4.14 \AA$ \\
\hline & 28 & & & & $4.19 \AA$ & & & \\
\hline \multirow[t]{8}{*}{ Odor } & 0 & 9.65 & 9.58 & 9.63 & 9.67 & 9.25 & 9.60 & 9.68 \\
\hline & 4 & 8.58 & 7.55 & 8.75 & 9.12 & 7.55 & 8.47 & 8.88 \\
\hline & 8 & $4.10 \AA$ & 6.58 & 7.05 & 7.82 & 6.58 & 7.58 & 8.40 \\
\hline & 12 & & $3.77 \AA$ & 6.30 & 7.68 & $4.18 \AA$ & 6.07 & 7.65 \\
\hline & 16 & & & $3.83 \AA$ & 6.95 & & $3.45 \AA$ & 7.50 \\
\hline & 20 & & & & 6.12 & & & 5.70 \\
\hline & 24 & & & & 5.80 & & & $3.97 \AA$ \\
\hline & 28 & & & & $3.92 \AA$ & & & \\
\hline \multirow[t]{8}{*}{ Texture } & 0 & 9.08 & 8.95 & 8.97 & 8.98 & 9.00 & 8.92 & 8.98 \\
\hline & 4 & 8.03 & 6.80 & 8.02 & 8.37 & 6.80 & 7.73 & 8.13 \\
\hline & 8 & $3.47 \AA$ & 5.77 & 6.20 & 7.47 & 5.73 & 6.73 & 7.55 \\
\hline & 12 & & $3.37 \AA$ & 5.45 & 6.82 & $3.33 \AA$ & 5.47 & 6.82 \\
\hline & 16 & & & $3.22 \AA$ & 6.02 & & $3.00 \AA$ & 6.57 \\
\hline & 20 & & & & 5.75 & & & 5.35 \\
\hline & 24 & & & & 5.27 & & & $3.52 \AA$ \\
\hline & 28 & & & & $3.48 \AA$ & & & \\
\hline
\end{tabular}

(B): At this point samples were rejected.

Table 5. Analysis of variance between treatments for sensory evaluation of sliced chicken during storage temperature $\left(4 \pm 1^{\circ} \mathrm{C}\right)$.

\begin{tabular}{|c|c|c|c|c|c|c|c|c|}
\hline \multirow{3}{*}{$\begin{array}{l}\text { Storage } \\
\text { period } \\
\text { (days) }\end{array}$} & \multirow{3}{*}{ D.F } & \multirow{3}{*}{ F crit } & \multicolumn{6}{|c|}{ F value and level of significance } \\
\hline & & & \multicolumn{2}{|c|}{ Appearance } & \multicolumn{2}{|c|}{ Odor } & \multicolumn{2}{|c|}{ Texture } \\
\hline & & & MS & $\mathbf{F}$ & MS & $\mathbf{F}$ & MS & $\mathbf{F}$ \\
\hline 0 & 6 & 2.37 & $0.01^{\text {NS }}$ & 0.80 & $0.14^{\mathrm{NS}}$ & 1.16 & $0.02^{\text {NS }}$ & 1.04 \\
\hline 4 & 6 & 2.37 & $2.36^{\star \star *}$ & 27.21 & $2.35^{\star \star \star}$ & 31.86 & $2.46^{\star \star *}$ & 28.36 \\
\hline 8 & 6 & 2.37 & $11.55^{\star \star \star}$ & 129.55 & $11.62^{\star * *}$ & 42.14 & $11.55^{\star \star \star}$ & 129.55 \\
\hline 12 & 5 & 2.53 & $14.65^{\star \star \star}$ & 172.20 & $16.70^{* \star *}$ & 192.84 & $14.65^{\star \star \star}$ & 172.21 \\
\hline 16 & 3 & 3.10 & $24.39^{* * *}$ & 177.39 & $26.13^{\star \star \star}$ & 215.65 & $20.62^{\star \star \star}$ & 149.94 \\
\hline 20 & 1 & 4.96 & $0.48^{* \star *}$ & 10.21 & $0.52^{\star \star \star}$ & 18.06 & $0.48^{\star \star *}$ & 10.21 \\
\hline 24 & 1 & 4.96 & $9.19^{\star \star \star}$ & 254.03 & $10.08^{* * *}$ & 270.10 & $9.19^{\star \star \star}$ & 254.03 \\
\hline
\end{tabular}

D.F, Degree of freedom; ** Significant at 0.05 . NS, Non significant. 


\section{REFERENCES}

Abdel-Daium MH (2007). Manufacturing of low-fat Chicken sausage and keeping its quality by gamma irradiation. Arab J. Nucl. Sci. Appl. 40: 296-304.

APHA (1992). Compendium of Methods for the Microbiological Examination of Foods,(2nd ed.), American Puplic Heath Association, Washinton DC.

Becker K, Koutsospyros A, Yin SM, Christodoulatos C, Abramzon N, Joaquin JC, No GBM (2005). Environmental and biological applications of microplasmas Plasma Phys. Control. Fusion 47, B513-B523.

Carvalho CM, Gannon BW, Halfhide DE, Santos SB, Hayes CM, Roe $\mathrm{JM}$, Azeredo J (2010). The in vivo efficacy of two administration routes of a phage cocktail to reduce numbers of Campylobacter coli and Campylobacter jejuni in chickens. BMC Microbiol. 10:232.

Deng XT, Shi JJ, Shama G, Kong MG (2005). Effects of microbial loading andsporulation temperature on atmospheric plasma inactivation of Bacillus subtilisspores. Appl. Phys. Lett. 87:153901.

Ehlbeck J, Brandenburg R, von Woedtke T, Krohmann U, Stieber M, Weltmann KD (2008). PLASMOSE - antimicrobial effects of modular atmospheric plasma sources. GMS Krankenhaushygiene Interdisziplin•ar 3(1):1-12

Ehlbeck J, Schnabel U, Polak M, Winter J, von Woedtke T, Brandenburg R, von dem Hagen T, Weltmann K-D (2011). Low temperature atmospheric pressure plasma sources for microbial decontamination. J. Phys. D: Appl. Phys. 44:18.

FDA, Food and Drug Administration (2002). Bacteriological Analytical Manual. $9^{\text {th }}$ Ed.,AOAC Int., Arlington,VA,USA.

Fernandez A, Shearer N, Wilson DR, Thompson A (2012). Effect of microbial loading on the efficiency of cold atmospheric gas plasma inactivation of Salmonella enterica serovar Typhimurium International. J. Food Microbiol. 152:175-180.

Foest R, Kindel E, Ohl A, Stieber M, Weltmann KD (2005). Non-thermal atmospheric pressure discharges for surface modification. Plasma Phys. Control. Fusion 47:B525-B536.

Jacobsreitsma WF, Bolder NM, Mulder RWAW (1994). Cecal Carriage of Campylobacter and Salmonella in Dutch broiler Flocks at slaughter - A one-Yearstudy. Poult. Sci. 73:1260-1266.

James C, James SJ, Hannay N, Purnell G, Barbedo-Pinto C, Yaman H, Araujo M, Gonzalez ML, Calvo J, Howell M, Corry JEL (2007). Decontamination of poultry carcasses using steam or hot water in combination with rapid cooling,chilling or freezing of carcass surfaces. Int. J. Food Microbiol. 114:195-203.

Kayes MM, Critzer FJ, Kelly-Wintenberg K, Roth JR, Montie TC, Golden DA (2007). Inactivation of foodborne pathogens using a one atmosphere uniform glowdischarge plasma. Foodborne Pathog. Dis. $4(1): 50-59$.
Massines F, Sarra-Bournet C, Fanelli F, Naude N, Gherardi N (2012). Atmospheric Pressure Low Temperature Direct Plasma Technology: Status and Challenges for Thin Film Deposition. Plasma Process. Polym. 9:1041-1073.

Montie TC, Kelly-Wintenberg K, Roth JR (2000). An overview of research using the one atmosphere uniform glow discharge plasma (OAUGDP) for sterilization of surfaces and materials. IEEE Trans. Plasma Sci. 28:41-50.

Moreau S (2000). Using the flowing afterglow of a plasma to inactivate Bacillussubtilis spores: Influence of the operating conditions. J. Appl. Phys. 88(2):1166-1174.

Muranyi P, Wunderlich J, Heise M (2007). Sterilization efficiency of a cascade dielectric barrier discharge. J. Appl. Microbiol. 103:15351544.

Murphy RY, Osaili T, Duncan LK, Marcy JA (2004). Thermal inactivation of Salmonella and Listeria monocytogenes in ground chicken thigh/leg meat and skin. Poult. Sci. 83:1218-1225

Oxoid,"The oxoid Manual" (1998). (8th ed.)Oxid Itd., Wade Road, Basingstoke, Hampshire, R G24 8PW, Engand.

Oyarzabal OA (2005). Reduction of Campylobacter spp. by commercial antimicrobialsapplied during the processing of broiler chickens: a review from the United States perspective. J. Food Prot. 68:17521760.

Rodriguez De Ledesma AM, Riemann HP, Farver TB (1996). Short-time treatmentwith alkali and/or hot water to remove common pathogenic and spoilage bacteria from chicken wing skin. J. Food Prot. 59:746750

Russell SM, Axtell SP (2005). Monochloramine versus sodium hypochlorite as antimicrobial agents for reducing populations of bacteria on broiler chickencarcasses. J. Food Prot. 68:758-763.

Shintani $H$ (2000). The reason for the dependency of $D$ value on the initial concentration of microorganisms. J. Antibacterial Antifungal Agents 28:680.

Vleugels M, Shama G, Deng XT, Greenacre E, Brocklehurst T, Kong MG (2005). Atmospheric plasma inactivation of biofilm-forming bacteria for food safetycontrol. IEEE Trans. Plasma Sci. 33:824-828.

Yoon KS (2003). Effect of gamma irradiation on the texture and microstructure of chicken breast meat. Meat Sci. 63:273.

Yu H, Perni S, Shi JJ, Wang DZ, Kong MG, Shama G (2006). Effects of cellssurface loading and phase of growth in cold atmospheric gas plasma inactivation ofEscherichia coli K12. J. Appl. Microbiol. 101:1323-1330.

Zar JH (1984). Biostatistical analysis. Prentice Hall,Englewood, N.J. pp. 718 